\title{
ПСИХОЛОГІЧНІ ОСОБЛИВОСТІ РОЗВИТКУ КОМУНІКАТИВНИХ НАВИЧОК ВЕДЕННЯ ПЕРЕГОВОРІВ У МАЙБУТНІХ СОЦІАЛЬНИХ ПРАЦІВНИКІВ
}

\author{
Валентина Санжаровець \\ кандидат філософських наук, доцент кафедри соціальних технологій \\ Національний авіаційний університет \\ 03058, Україна, м. Київ, проспект Любомира Гузара, 1 \\ valyasan@ukr.net, http://orcid.org/0000-0002-5213-9093
}

\section{Юлія Шатило}

кандидат психологічних наук, доцент кафедри соціальних технологій Національний авіаційний університет 03058, Україна, м. Київ, проспект Любомира Гузара, 1 yuliyashatylo89@gmail.com, http://orcid.org/0000-0002-5021-2787

\section{Анотація}

Статтю присвячено аналізу особливостей ефективного професійного спілкування майбутнього фахівця соціальної сфери. Кваліфікація майбутніх соціальних працівників передбачає сформованість багатьох компетентностей, якими повинен володіти випускник факультету лінгвістики та соціальних комунікацій, щоб бути конкурентоспроможним на ринку праці. До таких компетентностей належать: здатності референта, консультанта й експерта, вміння ведення переговорів з різних питань клієнтів соціальної роботи, надання соціальної допомоги, відстоювання інтересів дитини. Конкурентоспроможність на ринку праці також багато в чому залежить від здатності фахівця адаптуватися до умов, які часто змінюються. Успіх переговорів залежить від ефективності комунікативної поведінки майбутнього фахівця із соціальної роботи. Здатності до здійснення якісного ділового спілкування у різних (зокрема і проблемних) ситуаціях професійної взаємодії, вміння вести переговори на різних рівнях із представниками державних i недержавних організацій, професійно переконувати клієнтів, співрозмовників, встановлювати емоційний контакт, уважно слухати є необхідними компонентами фахівця соціальної служби. Однак, недостатній рівень розвитку в майбутніх соціальних працівників комунікативних навичок ведення переговорів, які $є$ важливим елементом у системі їхньої комунікативної компетентності, призводить до збільшення тривалості адаптації майбутнього фахівця в професійному середовищі і зниження успішності його діяльності. В результаті проведеного дослідження у багатьох досліджуваних виявлено досить високий показник агресії як домінуючої стратегії психологічного захисту; схильність до переважного застосування миролюбства як стратегії психологічного захисту, які, хоч і $€$ позитивними стратегіями, проте їх застосування у деяких ситуаціях професійної діяльності може свідчити про недостатню здатність майбутніх соціальних працівників відстоювати власну позицію, про зайву поступливість їх у спілкуванні 3 клієнтами. Визначено досить велику кількість досліджуваних із низьким рівнем комунікативного 
контролю, що, вочевидь, знижує ефективність їх професійного спілкування через зайву прямолінійність і нав'язливість.

Ключові слова: професійно-комунікативна компетентність, фахівці соціальної сфери, інформаційно-комунікативний компонент, експресивно-перцептивний компонент, міжособистісний компонент.

\section{Вступ}

Сьогодні, в умовах динамічного розвитку українського суспільства, інтенсивного виходу вітчизняних соціальних служб на зовнішній ринок, що впливає на розвиток та підвищення авторитету України на міжнародній арені, виникає нагальна потреба у підготовці висококваліфікованих фахівців із соціальної роботи, що $є$ запорукою ефективності соціокультурного розвитку держави. Зазначене зумовлює необхідність зміни спрямованості сучасної освіти на активне навчання, підвищення відповідальності студента, розширення його автономії, розвиток у студентів спеціальності «Соціальна робота» таких компетентностей, що відповідають стратегічним планам соціальних служб, як вітчизняного, так і світового ринку праці. Ефективність досягнення мети у професійній діяльності потребує, передусім, розвитку особистості соціального працівника (Петренко \& Санжаровець, 2018). Основним інструментом майбутньої професійної діяльності досліджуваних є робота з клієнтами, що потрапили в складні життєві обставини.

Досить часто у соціальних працівників виникає боротьба між силою та безсиллям перед клієнтами, яким вони прагнуть допомогти (Bundy-Fazioli, 2004; Pitcher, 2008). BarOn у своїх дослідженнях стверджує, що професія соціального працівника «опановувала дискурс влади та ефективно ii використовувала» (Bar-On, 2002: 998). Соціальний працівник повинен розуміти, що клієнту відмовитися від звичного життя, відомого 3 дитинства, і зробити крок до чогось нового - важко; це вимагає зусиль (Koval, Sanzharovets \& Shatylo, 2020). Щоб виконати таке завдання, викладачі повинні залучати студентів до критичного мислення щодо їх сприйняття та розуміння професійної сили на практиці (Bundy-Fazioli, Quijano \& Bubar, 2013).

Вихід із таких обставин залежить від ефективності комунікативної поведінки фахівця, його здатності спілкуватися в усіх ситуаціях професійної взаємодії (зокрема i проблемних); підтримувати діалог на різних рівнях із кожним клієнтом; здатності переконувати, встановлювати емоційний контакт, активно слухати. Структура почуттів особистості презентує ступінь засвоєння соціального досвіду i визначає провідні мотиваційні орієнтації й особливості самовідчуття (Kariaka, 2017). Недостатній рівень розвитку у майбутніх фахівців соціальної сфери комунікативних навичок ведення діалогу призводить до збільшення тривалості адаптації молодого спеціаліста в професійному середовищі й зниження успішності його діяльності.

Наукова спільнота надає велику увагу дослідженню психологічних закономірностей спілкування в процесі ведення переговорів як таких (Jonsson, 1990; Stein, 1998), а також i вивченню їхніх проявів, зокрема: особливостям переговорів в екстремальних умовах (Thomson, 1990); переговорам, як засобу запобігання і розв'язання конфліктів (Анцупов, 2002, Хасан, 2008); психологічним особливостям прояву рефлексії в процесі переговорів (Brett \& Thompson, 2016); формування та розвитку комунікативних умінь і навичок ведення переговорів (Спинова, 2007; Якимчук, 2008; McGuire, 2004) та ін. 
Велику кількість досліджень було присвячено значенню впливу особистісних особливостей на поведінку під час переговорів і результати (Bazerman, Curhan, Moore \& Valley, 2000; Cellich, 2012; Sharma, Bottom \& Elfenbein, 2013; Блінов, 2013; Шатило, 2016).

Аналіз наукових досліджень з обраної теми засвідчує, що проблема переговорів отримала своє висвітлення в працях учених, однак, недостатньо вивченим залишається питання розвитку комунікативних навичок ведення переговорів, зокрема й у майбутніх соціальних працівників.

Мета дослідження: теоретично обгрунтувати та емпірично дослідити психологічні особливості розвитку комунікативних навичок ведення переговорів у майбутніх соціальних працівників. Для досягнення поставленої мети було визначено такі завдання: 1) виокремити і дослідити компоненти підготовки майбутніх соціальних працівників до ведення переговорів; 2) виявити психологічні особливості розвитку та визначити рівні сформованості комунікативних навичок ведення переговорів у майбутніх соціальних працівників.

\section{Методи дослідження}

В емпіричному дослідженні брали участь 32 особи (студенти 4 курсу спеціальності «Соціальна робота» Національного авіаційного університету, м. Києва): 12 чоловіків (віком від 19 до 21 років) та 20 жінок (віком від 19 до 22 років).

Для емпіричного дослідження були обрано методики, які спрямовані на діагностику психологічних чинників підготовки майбутніх соціальних працівників до ведення переговорів, а саме: 1) методика виявлення комунікативних і організаторських схильностей (КОС-2) В. В. Синявського, Б. А. Федоришина (Фетискин, Козлов \& Мануйлов, 2002); 2) методика діагностики домінуючої стратегії психологічного захисту в спілкуванні за В. В. Бойком (Бойко, 2001); 3) «Тест оцінки самоконтролю в спілкуванні» М. Снайдера (Карелин, 2007); 4) тест «Чи вмієте Ви слухати співрозмовника?» Д. Я. Райгородского (Райгородский, 1998).

Методика виявлення комунікативних і організаторських схильностей (КОС-2). Застосування цієї методики дозволило оцінити здатність майбутніх соціальних працівників чітко і швидко встановлювати ділові та товариські контакти 3 людьми, діагностувати уміння брати участь в суспільних і групових заходах, уміння впливати на людей.

«Тест оцінки самоконтролю в спілкуванні» М. Снайдера. Застосування цього тесту в дослідженні дозволило виявити здатність студентів до самоконтролю у спілкуванні. Ця здатність $\epsilon$ важливою для майбутніх соціальних працівників, адже нестримана, імпульсивна поведінка викликає в оточуючих психічний дискомфорт, може провокувати міжособистісні конфлікти у їх професійній взаємодії.

Тест «Чи вмієте ви слухати співрозмовника?» Д. Я. Райгородского. Застосування цього тесту в дослідженні дозволило оцінити уміння слухати майбутніх соціальних працівників. Особливо необхідно таке вміння соціальному працівнику, оскільки уміння слухати - найважливіша складова частина його комунікативної компетентності. 


\section{Результати та дискусії}

Для фахівців соціальної сфери, крім комунікативної компетентності, важливе місце займає міжкультурна комунікативна компетентність. В. I. Нароліна стверджує, що міжкультурна комунікація - це здатність досягати взаєморозуміння між представниками різних культур, навіть, якщо рівень володіння мовою партнера знаходиться на низькому рівні, що відбувається на основі знань, розуміння та дотримання правил й норм поведінки, які складають основу міжнародного етикету спілкування (Наролина, 2008).

Майбутній фахівець соціальної сфери повинен володіти: умінням системно і креативно мислити; здатністю виявляти ініціативу; визначати проблеми, які з'являються у професійній діяльності; готовністю брати відповідальність за свої дії у рамках компетенції та приймати нестандартні рішення; вирішувати життєві ситуації клієнтів; виявляти лідерські та менеджерські якості (Абрамович, 2018).

Професійно-комунікативна компетентність $є$ невід’ємною частиною майбутньої професійної діяльності студентів-соціальних працівників. Адже вона віддзеркалює всі особистісні якості та властивості фахівця, за допомогою яких він самостійно й ефективно реалізує завдання професійної діяльності (Шломенко, 2008).

Аналіз результатів методики КОС-2 дозволив визначити рівень комунікативних та організаторських схильностей досліджуваних, a саме уміння чітко $\mathrm{i}$ швидко встановлювати ділові та товариські контакти з людьми, брати участь у суспільних і групових заходах, впливати на людей, а також прагнення до поширення сфери контактів та прояву ініціативи (див. табл. 1).

Таблиия 1

Кількість досліджуваних майбутніх соціальних працівників 3 різними рівнями комунікативних та організаторських схильностей (за методикою КОС-2)

\begin{tabular}{|l|c|c|c|c|c|c|}
\hline \multirow{2}{*}{ Схильності } & \multicolumn{3}{|c|}{ Рівень прояву комунікативних та організаторських схильностей } \\
\cline { 2 - 7 } & \multicolumn{2}{|c|}{ Низький } & \multicolumn{2}{|c|}{ Середній } & \multicolumn{2}{|c|}{ Вищий } \\
\cline { 2 - 7 } & $\begin{array}{c}\text { Кількість } \\
\text { осіб }\end{array}$ & $\begin{array}{c}\text { Кількість } \\
\text { осіб у \% }\end{array}$ & $\begin{array}{c}\text { Кількість } \\
\text { осіб }\end{array}$ & $\begin{array}{c}\text { Кількість } \\
\text { осіб у \% }\end{array}$ & $\begin{array}{c}\text { Кількість } \\
\text { осіб }\end{array}$ & $\begin{array}{c}\text { Кількість } \\
\text { осіб у \% }\end{array}$ \\
\hline Комунікативні & 14 & 44 & 10 & 31 & 8 & 25 \\
\hline Організаторські & 15 & 47 & 9 & 28 & 8 & 25 \\
\hline
\end{tabular}

Аналіз результатів вивчення комунікативних і організаторських схильностей за допомогою методики КОС-2 (табл. 1) засвідчив, що 31\% досліджуваних мають середній рівень комунікативних здібностей і $28 \%$ - середній рівень організаторських схильностей. Це свідчить про те, що вони, зазвичай, прагнуть до контактів із людьми, не обмежують коло своїх знайомств, відстоюють власну думку, планують свою роботу, проте потенціал їх схильностей не вирізняється високою сталістю. Переважна більшість досліджуваних мають низький рівень комунікативних та організаторських схильностей (44\% і 47\% осіб, відповідно). На нашу думку, знижений рівень розвитку комунікативних і організаторських схильностей негативно позначається на ефективності виконання досліджуваними їх професійних обов'язків, тому потребує відповідної корекційної роботи.

Зовсім невелика частина досліджуваних мають високий рівень комунікативних та організаторських схильностей (25\% і 25\% осіб, відповідно), а, отже, для них характерні відсутність страху першого контакту і незнайомої обстановки, вміння швидко знаходити контакт, прагнення займатися громадською діяльністю, допомагати іншим. 
Потреба психологічного захисту визначається, на думку Е. І. Киршбаум i А. І. Єремєєвої (Киршбаум \& Еремеева, 1990), суб’єктивною значущістю події для людини. Такий спосіб застосовується в ситуаціях ускладнення або перешкод, а, отже, психологічний захист ініціюється винятковими, гострими ситуаціями.

Отримані результати за методикою діагностики домінуючої стратегії психологічного захисту в спілкуванні (за методикою В. В. Бойка) подано на рис. 1.

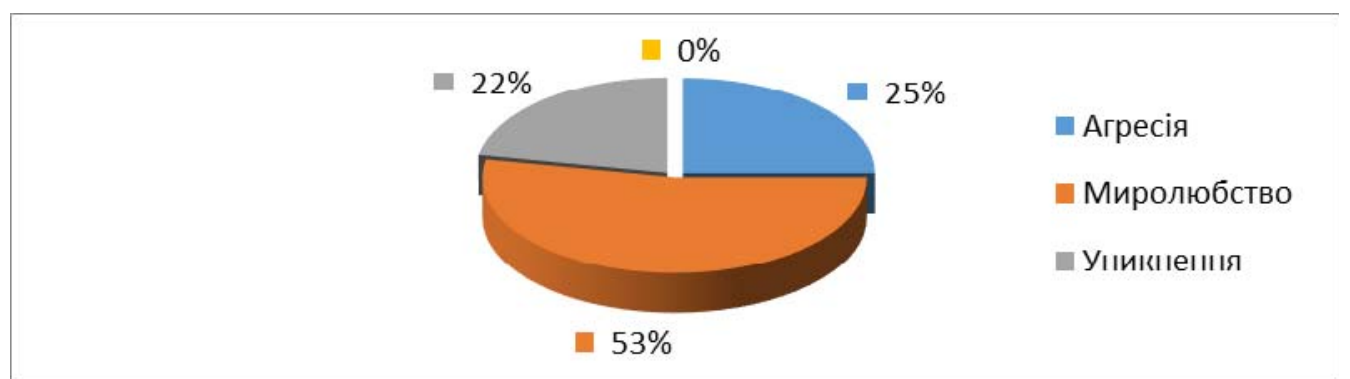

\section{Рис. 1. Домінуючі стратегії психологічного захисту в спілкуванні майбутніх соціальних працівників (дані у \%)}

Як видно 3 рис. 1, найбільша кількість студентів (53\%) осіб надає перевагу миролюбству, тобто психологічній стратегії захисту суб'єктної реальності особистості, в якій провідну роль виконують інтелект і характер. Досліджувані, у яких домінуючою стратегією $є$ миролюбство, припускають партнерство й співробітництво, вміють йти на компроміси. На нашу думку, ця стратегія виявляється в професійному спілкуванні 3 клієнтами і партнерами, в процесі переговорів, як здатність до співробітництва та пошуку компромісних рішень у розв'язанні суперечливих питань.

Привертають увагу дані, що в четвертої частини студентів (25\%) переважає агресія, тобто така психологічна стратегія захисту суб'єктної реальності особистості, що діє на основі інстинкту. Це свідчить про те, що такі досліджувані схильні до конфліктної поведінки у складних ситуаціях професійної взаємодії. Найменша кількість студентів (22\%) надає перевагу уникненню - психологічній стратегії захисту суб'єктної реальності, заснованій на економії інтелектуальних й емоційних ресурсів. Згідно інтерпретації цієї методики, такі особи зазвичай уникають або «без бою» залишають зони конфліктів i напруг, якщо їхнє Я піддається атакам. При цьому вони відкрито не витрачають енергію емоцій і мінімально напружують інтелект. Така поведінка у складних умовах професійної взаємодії може призводити до відмови від захисту власної позиції у суперечливих питаннях, що знижує ефективність виконання ними професійних обов’язків.

Для оцінки самоконтролю студентів у спілкуванні застосовувався тест М. Снайдера (див. рис. 2). Як видно з рис. 2, переважна кількість досліджуваних (41\%) має високий комунікативний контроль, що свідчить про їх здатність легко виконувати будь-яку роль, гнучко реагувати на зміну ситуації, передбачити враження, яке вони справляють на інших. Студенти 3 високим комунікативним контролем постійно стежать за собою, добре керують своїми емоційними проявами. Водночас вони мають значні труднощі в спонтанності самопрояву, не люблять непрогнозованих ситуацій. На нашу думку, високий комунікативний контроль у роботі майбутніх соціальних працівників $\epsilon$ умовою професійної ефективності, адже більшість їх робочого часу витрачається на різні види 
спілкування. Значна частина студентів має середній комунікативний контроль (31\%), а, отже, їм властива щирість, але недостатня стриманість у своїх емоційних проявах. Однак недостатня стриманість у емоційних проявах може призвести до появи помилок у вирішенні стратегічних питань.

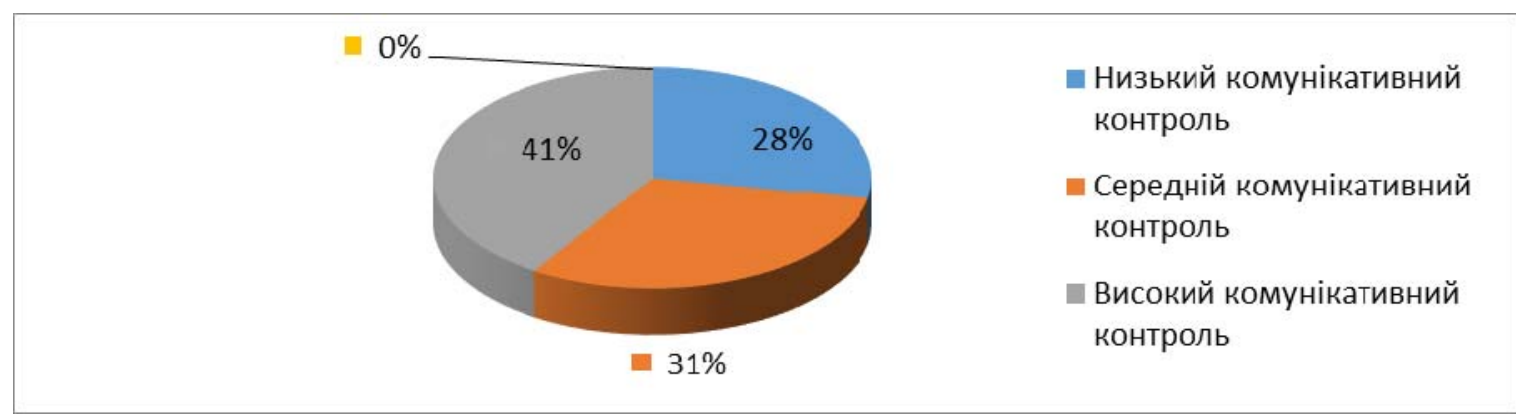

\section{Рис. 2. Особливості комунікативного контролю майбутніх соціальних працівників (дані у \%)}

Дещо менша кількість досліджуваних (28\%) має низький комунікативний контроль. Їм властива стійка поведінка, вони не вважають за потрібне змінюватися залежно від ситуацій. Низький рівень комунікативного контролю, на нашу думку, може негативно позначатися на професійній діяльності, передусім, у взаємодії з клієнтами, зумовлювати виникнення міжособистісних конфліктів через високий рівень імпульсивності у спілкуванні. Надто вільна поведінка в процесі переговорів також може засвідчувати невиразні уявлення про моральні норми особистості.

Аналіз результатів тесту «Чи вмієте ви слухати співрозмовника?». Середній показник вміння слухати у досліджуваних складає 48,4 бали. Зважаючи на те, що більше 62 балів - це слухач «вище середнього рівня», а середній бал слухачів - 55, можна констатувати недостатньо задовільний рівень розвитку уміння слухати у більшості студентів загалом. Тобто, майбутнім соціальним працівникам властиві неуважність, схильність робити передчасні висновки, нездатність зрозуміти співрозмовника.

Отже, результати емпіричного дослідження свідчать про незадовільний стан комунікативних і організаторських схильностей, як основних елементів комунікативних здібностей майбутніх соціальних працівників до проведення переговорів, з урахуванням того, що для майбутніх соціальних працівників міжособистісне спілкування виступає основною формою взаємодії з клієнтами чи з колегами або керівництвом, а, отже, вимагає чіткого орієнтування в професійній ситуації і вибору саме тих засобів спілкування, які є для iii розв'язання найбільш ефективними. Виявлено досить велику частину досліджуваних з переважанням агресії, домінуючої стратегії психологічного захисту, як цілеспрямованої руйнівної, наступальної поведінки, що порушує норми і правила співіснування людей у суспільстві, викликає в інших психічний дискомфорт, негативні переживання страху, напруженості, пригніченості. Також установлено досить велику кількість майбутніх соціальних працівників із низьким рівнем комунікативного контролю, що, вочевидь, знижує ефективність їх професійного спілкування через зайву прямолінійність, імпульсивність у спілкуванні. Незадовільними також є показники вміння слухати, як базового складника комунікативних здібностей майбутніх соціальних працівників до проведення переговорів. Отже, результати емпіричного дослідження 
підтвердили необхідність подальшої серйозної й планомірної роботи 3 розвитку комунікативних здібностей майбутніх соціальних працівників.

Залежною змінною у дослідженні $\epsilon$ стратегія спілкування: миролюбство, уникнення або агресія (методика діагностики домінуючої стратегії психологічного захисту у спілкуванні за В. В. Бойком).

Оскільки непараметричний критерій Колмогорова-Смірнова за усіма шкалами методик, використаних у роботі, засвідчив, що розподіл змінних за шкалами комунікативні схильності (рівень значущості 0,082), організаторські схильності (рівень значущості 0,096), самоконтроль (рівень значущості 0,340), вміння слухати (рівень значущості 0,516), миролюбство (рівень значущості 0,435), уникнення (рівень значущості 0,595) та агресія (рівень значущості 0,538) в студентів відповідає нормальному, то для кореляційного аналізу застосовувався критерій Пірсона (див. табл. 2). Цей критерій використовується при нормальному розподілі вибірки, кількість досліджуваних якої не менше 30 чоловік.

Таблиия 2

Показник значущих зв'язків «стратегії агресії» із «організаторськими здібностями» та «самоконтролем» у майбутніх соціальних працівників

\begin{tabular}{|c|c|c|c|}
\hline & За критерієм Пірсона & Організаторські здібності & Самоконтроль \\
\hline \multirow{2}{*}{$\begin{array}{c}\text { Стратегія } \\
\text { агресії }\end{array}$} & Показник кореляції & $0,535^{*}$ & $-0,617^{* *}$ \\
\cline { 2 - 4 } & Показник значущості & 0,022 & 0,006 \\
\hline
\end{tabular}

Примітка. **Кореляція значуща на рівні 0,01. *Корелящуія значущуа на рівні 0,05.

3 табл. 2 видно, що існує прямий кореляційний зв'язок (рівень значущості 0,022) між вибором стратегії агресії та організаторськими схильностями майбутніх соціальних працівників (показник кореляції 0,535). Це свідчить про те, що чим більше у респондента розвинені організаторські схильності, чим більше він орієнтується у новій компанії, шукає нові знайомства і не боїться вирішувати проблеми, здатен приймати рішення у складних, нестандартних ситуаціях, тим більше він використовуватиме стратегію агресивну психологічного захисту. Для агресивної стратегії психологічного захисту притаманні високий рівень інтелекту, вміння відстоювати власну думку і межі особистості, прямолінійність. Також установлено тісний непрямий (показник кореляції -0,617) взаємозв'язок між рівнем самоконтролю та проявом стратегії агресії (показник значущості 0,006). Тобто, чим більше відсутній самоконтроль у респондента, тим більше він застосовуватиме стратегію агресії в переговорах.

Зв’язки показників «стратегії миролюбства» із «вмінням слухати» у майбутніх соціальних працівників подано в табл. 3 .

Таблиия 3

Показник значущих зв'язків показників «стратегії миролюбства» із «вмінням слухати» у майбутніх соціальних працівників

\begin{tabular}{|c|c|c|}
\hline & За критерієм Пірсона & Вміння слухати \\
\hline \multirow{2}{*}{$\begin{array}{c}\text { Стратегія } \\
\text { миролюбства }\end{array}$} & Показник кореляції & $0,881^{* *}$ \\
\cline { 2 - 3 } & Показник значущості & 0,001 \\
\hline
\end{tabular}

Примітка. **Корелячүiя значущуа на рівні 0,01. 
3 табл. 3 помітно, що наявний прямий статистичний взаємозв'язок (показник кореляції 0,881) стратегії миролюбства із вмінням слухати (показник значущості 0,001). Це означає, що чим більше досліджуваний здатен бути хорошим слухачем, сприймати нову інформацію, зокрема негативну, тим більше в нього розвинена стратегія миролюбства. Для людини із стратегією миролюбства властиві партнерство і співробітництво, уміння йти на компроміси, здійснювати вчинки і бути податливим.

Досліджено, які саме компоненти впливають на стратегію агресії та миролюбства у веденні переговорів майбутніх соціальних працівників (див. табл. 4).

Таблиия 4

Показники коефіціснтів регресійного аналізу значущого впливу комунікативних чинників на домінуючу стратегію поведінки майбутніх соціальних працівників

\begin{tabular}{|c|c|c|c|c|}
\hline Шкала & Вета & $\begin{array}{c}\text { Рівень } \\
\text { значущості }\end{array}$ & $\begin{array}{c}\text { В домінуючої } \\
\text { стратегії }\end{array}$ & В (показника) \\
\hline Самоконтроль & 0,832 & 0,001 & 3,430 & $-0,055$ \\
\hline Вміння слухати & 0,679 & 0,001 & 2,691 & 0,074 \\
\hline
\end{tabular}

Як помітно з табл. 4, щодо стратегії миролюбства, великий вплив на рівень іiі застосування має показник «вміння слухати» (рівень значущості 0,001). За стандартизованим показником (Вета 0,679$)$ відзначимо, що вплив доволі значущий.

Регресійну модель міри впливу вміння слухати на стратегію миролюбства подано формулою Y2: Y2=2,691+0,074 (вміння слухати). 3 формули Y2 зрозуміло, що вміння слухати позитивно впливає на розвиток стратегії миролюбства, партнерства, партнерства та взаєморозуміння. Проводячи загальний аналіз отриманих регресивних моделей (Y2Y2), можемо відзначити, що на стратегію агресії у переговорах обернено впливає здатність самоконтролю особистості в процесі спілкування. Тобто, аби зменшувати власні агресивні, нестримні, вибухові прояви, варто вміти стримуватись, керувати власним настроєм, емоціями, реакціями на обставини.

На стратегію миролюбства у веденні переговорів майбутніми соціальними працівниками прямо впливає їх вміння слухати, бути уважним у спілкуванні, не перебивати партнера, намагатися його зрозуміти. За допомогою методу регресійного аналізу було встановлено, що на стратегію агресії впливає рівень самоконтролю респондента, на стратегію миролюбства впливає вміння слухати партнера на переговорах, на що варто зважати в процесі розробки програми з розвитку комунікативних навичок ведення переговорів у майбутніх соціальних працівників.

\section{Висновки}

Враховуючи теоретичний аналіз професійно-комунікативної компетентності студентів-міжнародників та особливостей ведення ділових переговорів у руслі нашого дослідження, під комунікативними навичками ведення переговорів розуміємо особистісні ресурси майбутніх фахівців 3 міжнародних відносин, які $\epsilon$ результатом набуття у навчально-професійній діяльності індивідуального досвіду, необхідного для встановлення ефективної взаємодії на всіх етапах ведення переговорного процесу.

Виявлено, що досить велика кількість студентів мають низький рівень розвитку комунікативних і організаторських схильностей, а, отже, не здатні чітко орієнтуватися в професійній ситуації і обирати саме ті засоби спілкування, що є найбільш ефективними 
для іiі розв’язання. Ці досліджувані відчувають труднощі у встановленні контактів із клієнтами, не відстоюють свою думку, важко переживають образи, уникають прийняття самостійних рішень, а прояв ініціативи у професійній діяльності у них вкрай занижений.

Встановлено, що у багатьох студентів досить високий показник агресії, як домінуючої стратегії психологічного захисту. Водночас у більшості студентів виявлено схильність до переважного застосування миролюбства, як стратегії психологічного захисту, що сповнена позитивного змісту. Проте іiі застосування у деяких ситуаціях професійної діяльності може свідчити про недостатню здатність майбутніх соціальних працівників відстоювати власну позицію, про їхню зайву поступливість у спілкуванні 3 клієнтами. Помічено досить велику кількість студентів із низьким рівнем комунікативного контролю, що знижує ефективність їх професійного спілкування через зайву прямолінійність і нав'язливість. Низький рівень і показників уміння слухати, як базового складника комунікативних здібностей майбутніх соціальних працівників.

Перспективи дослідження вбачаємо в розробці психолого-педагогічної програми розвитку комунікативних навичок ведення переговорів у майбутніх фахівців соціальної сфери.

\section{Література}

1. Абрамович, Т.В. (2018). Розвиток професійної компетентності соиіального педагога у системі післядипломної освіти. (Дис. канд. пед. наук). Рівне.

2. Анцупов, А.Я. (2002). Конфликтология (2-е изд.). Москва : ЮНИТИДИ-ДАНА.

3. Блінов, О.А. (2013). Психологічне забезпечення переговорного процесу. Київ : НАУ.

4. Бойко, В.В. (2001). Методика диагностики доминирующей стратегии психологической защиты в общении. Самара : Издательский Дом «БАХРАХ-М».

5. Карелин, А. (2007). Больиая энциклопедия психологических тестов. Москва : Эксмо.

6. Киршбаум, Э.И., \& Еремеева, А.И. (1990). Психические состояния. Владивосток : Изво Дальневосточного университета.

7. Наролина, В.И. (2008). Развивающий эффект процесса формирования межкультурной коммуникативной компетентности специалиста. Высшее образование сегодня, 5, 23-25.

8. Петренко, Т.В., \& Санжаровець, В.М. (2018). Сучасні технології у підготовці фахівців соціальної сфери. Вісник Національного авіаційного університету, 13, 131-136. https://doi.org/\%2010.18372/2411-264X.13.13408

9. Райгородский, Д.Я. (2001). Практическая психодиагностика. Методики и тестьл. Самара : Издательский дом «БАХРАХ-М».

10. Спэнг, М., \& Айзенхарт, М. (2009). Переговоры. Решение проблем в разном контексте. Харьков : Гуманитарный Центр.

11. Спинова, Е.А. (2007). Формирование умений ведения переговоров при языковой подготовке специалистов внешней торговли: английский язык, стариий этап обучения экономического вуза. (Дисс. канд. пед. наук). Москва.

12. Фетискин, Н.П., Козлов, В.В., \& Мануйлов, Г.М. (2002). Соџиально-психологическая диагностика развития личности и мальых групn. Москва: Изд-во Института Психотерапии.

13. Хасан, Б.И., \& Сергоманов П.А. (2008). Психология конфликта и переговоры (4-е изд.). Москва : Академия.

14. Шатило, Ю.П. (2016). Розвиток комунікативних навичок ведення переговорів у студентів-міжснародників. (Дис. канд. психол. наук). Київ.

15. Шломенко, Е.Б. (2008). Формирование и развитие профессиональной направленности студентов - будущих экономистов в процессе обучения иностранному язику. Матеріали Всеукраӥнської науково-практичної конферениї "Сучасна освіта творчо обдарованої молоді: ідеї, технологї̈, перспективи» (м. Кривий Ріг, 16-18 квітня 2008 р.). (с. 144-149). Кривий Ріг : АПН України, Ін-т обдар. дитини АПН України, Криворіз. держ. пед. ун-т.

16. Якимчук, Ю.В. (2008). Психологічні особливості інтенсифікачї розвитку комунікативних здібностей майбутніх фахівців міжнародних відносин (Автореф. дис. канд. психол. наук). Хмельницький. 
17. Bar-On, A. (2002). Restoring power to social work practice. British Journal of Social Work, 32(8), 997-1014. https://doi.org/10.1093/bjsw/32.8.997

18. Bazerman, M.H., Curhan, J.R., Moore, D.A., \& Valley, K.L. (2000). Negotiation. Annual Review of Psychology, 51, 279-314. https://doi.org/10.1146/annurev.psych.51.1.279

19. Brett, J., \& Thompson, L. (2016). Negotiation. Organizational Behavior and Human Decision Processes, 136, 68-79. https://doi.org/10.1016/j.obhdp.2016.06.003

20. Bundy-Fazioli, K.(2004). Exploring the distribution of power in child welfare practice: Who holds the power to create change? A qualitative study, (Doctoral dissertation). Available from ProQuest Dissertations and Theses database. (UMI No. 3148025)

21. Bundy-Fazioli, K., Quijano, M.L., \& Bubar, R. (2013). Graduate Students' Perceptions of Professional Power in Social Work Practice. Journal of Social Work Education, 49(1), 108-121. https://doi.org/10.1080/10437797.2013.755092

22. Cellich, C., \& Jain S. (2012). Practical Solutions to Global Business Negotiations. New York: Business Expert Press.

23. Jonsson,Ch. (1990). Communication in International Bargaining. London: Pinter Publishers.

24. Kariaka, I. (2017). Value-semantic orientations as a factor of students-psychologists' behavior forming. Наука і освіта, 11, 146-150.

https://doi.org/10.24195/2414-4665-2017-11-19

25. Koval, G., Sanzharovets, V., \& Shatylo, Yu. (2020). Social Works in Certain Areas of Donetsk and Lugansk Regions. Atlantis Press. Advances in Economics, Business and Management Research, 129, 361-369. https://doi.org/10.2991/aebmr.k.200318.045

26. McGuire, R. (2004). Negotiation: An important life skill. The Pharmaceutical Journal (PJ), $273, \quad 23-25$. Retrieved from https://www.pharmaceutical-journal.com/careers-andjobs/careers-and-jobs/career-feature/negotiation-an-important-life-skill/10997072.article

27. Pitcher, D. (2008). Social work and power [Review of the book Social work and power, by R. Smith]. British Journal of Social Work, 38, 1660-1662.

https://doi.org/10.1093/bjsw/bcn158

28. Sharma, S., Bottom, W.P., \& Elfenbein, H.A. (2013). On the role of personality, cognitive ability, and emotional intelligence in predicting negotiation outcomes. Organizational Psychology Review, 3(4), 293-336. https://doi.org/10.1177/2041386613505857

29. Stein, J.G. (1988). International Negatiation: A Multidisciplinary Perspective. Negotiation Journal, 4, 221-231. https://doi.org/10.1111/j.1571-9979.1988.tb00467.x

30. Thomson, L. (1990). Negotiation behavior and outcomes: Empirical evidence and theoretical issues. Psychological Bulletin, 108(3), 515-532.

https://doi.org/10.1037/0033-2909.108.3.515

\section{References}

1. Abramovych, T.V. (2018). Rozvytok profesiinoi kompetentnosti sotsialnoho pedahoha u systemi pisliadyplomnoi osvity [Development of professional competence of social teacher in the system of postgraduate education]. Candidate's thesis. Rivne [in Ukrainian].

2. Antsupov, A.Ya. (2002). Konfliktologiya [Conflictology] (2nd. en). Moskva : YUNITIDIDANA [in Russian].

3. Blinov, O.A. (2013). Psykholohichne zabezpechennia perehovornoho protsesu [Psychological support of the negotiation process]. Kyiv : NAU [in Ukrainian].

4. Bojko, V.V. (2001). Metodika diagnostiki dominirujushhej strategii psihologicheskoj zashhity $v$ obshhenii [Diagnostic technique for the dominant strategy of psychological defense in communication]. Samara : Izdatel'skiy Dom «BAKHRAKH-M» [in Russian].

5. Karelin, A. (2007). Bol'shaya entsiklopediya psikhologicheskikh testov [Big encyclopedia of psychological tests]. Moskva : Eksmo [in Russian].

6. Kirshbaum, E.I., \& Yeremeyeva, A.I. (1990). Psikhicheskiye sostoyaniya [Mental states]. Vladivostok : Iz-vo Dal'nevostochnogo universiteta [in Russian].

7. Narolina, V.I. (2008). Razvivajushhij jeffekt processa formirovanija mezhkul'turnoj kommunikativnoj kompetentnosti specialista [Developing effect of the process of formation of intercultural communicative competence of a specialist]. Vyssheye obrazovaniye segodnya - Higher education today, 5, 23-25. [in Russian].

8. Petrenko, T.V., \& Sanzharovets', V.M. (2018). Suchasni tekhnolohiyi u pidhotovtsi fakhivtsiv sotsial'noyi sfery [Modern technologies in training social specialists]. Visnyk Natsional'noho aviatsiynoho universytetu - Bulletin of the National Aviation University, 13, 131-136. https://doi.org/\%2010.18372/2411-264X.13.13408 [in Ukrainian]. 
9. Rajgorodskij, D.Ja. (1998). Prakticheskaja psihodiagnostika. Metodiki $i$ testy [Psychodiagnostics of staff. Methodology and tests]. Samara : Izdatel'skiy Dom «Bakhrakh» [in Russian].

10. Speng, M., \& Ayzenkhart, M. (2009). Peregovory. Resheniye problem v raznom kontekste [Conversation. Problem solving in a different context.]. Kharkiv : Gumanitarnyy Tsentr [in Ukrainian].

11. Spinova, Ye.A. (2007). Formirovaniye umeniy vedeniya peregovorov pri yazykovoy podgotovke spetsialistov vneshney torgovli: angliyskiy yazyk, starshiy etap obucheniya ekonomicheskogo vuza [Formation of negotiation skills in the language training of foreign trade specialists: English, the senior stage of study at an economic university]. Candidate's thesis. Moskva [in Russian].

12. Fetiskin, N.P., Kozlov, V.V., \& Manuylov, G.M. (2002). Sotsial'no-psikhologicheskaya diagnostika razvitiya lichnosti $i$ malykh grupp [Socio-psychological diagnosis of the development of personality and small groups]. Moskva : Izd-vo Instituta Psikhoterapii [in Russian].

13. Khasan, B.I., \& Sergomanov, P.A. (2008). Psikhologiya konflikta $i$ peregovory [The Psychology of Conflict and Negotiation] (4th ed.). Moskva : Akademiya [in Russian].

14. Shatylo, Yu.P. (2016). Rozvytok komunikatyvnykh navychok vedennia perehovoriv u studentiv-mizhnarodnykiv [The development of communication skills in negotiation of international students.]. Candidate's thesis. Kyiv [in Ukrainian].

15. Shlomenko, E.B. (2008). Formirovaniye i razvitiye professional'noy napravlennosti studentov - budushchikh ekonomistov $\mathrm{v}$ protsesse obucheniya inostrannomu yaziku [The formation and development of the professional orientation of students - future economists in the process of teaching a foreign language]. Materialy Vseukrayins'koyi naukovopraktychnoyi konferentsiyi "Suchasna osvita tvorcho obdarovanoyi molodi: ideyi, tekhnolohiyi, perspektyvy" - Proceedings of the All-Ukrainian Scientific-Practical Conference "Contemporary Education of Creatively Gifted Youth: Ideas, Technologies, Prospects" (Kryvyy Rih, April 16-18, 2008). (pp. 144-149). Kryvyy Rih : APN Ukrayiny, Int obdar. dytyny APN Ukrayiny, Kryvoriz. derzh. ped. un-t. [in Ukrainian].

16. Yakymchuk, YU.V. (2008). Psykholohichni osoblyvosti intensyfikatsiyi rozvytku komunikatyvnykh zdibnostey maybutnikh fakhivtsiv mizhnarodnykh vidnosyn [Psychological peculiarities of intensification of development of communicative abilities of future specialists of international relations]. Extended abstract of Candidate's thesis. Khmelnytskyi [in Ukrainian].

17. Bar-On, A. (2002). Restoring power to social work practice. British Journal of Social Work, 32(8), 997-1014. https://doi.org/10.1093/bjsw/32.8.997

18. Bazerman, M.H., Curhan, J.R., Moore, D.A., \& Valley, K.L. (2000). Negotiation. Annual Review of Psychology, 51, 279-314. https://doi.org/10.1146/annurev.psych.51.1.279

19. Brett, J., \& Thompson, L. (2016). Negotiation. Organizational Behavior and Human Decision Processes, 136, 68-79. https://doi.org/10.1016/j.obhdp.2016.06.003

20. Bundy-Fazioli, K. (2004). Exploring the distribution of power in child welfare practice: Who holds the power to create change? A qualitative study, (Doctoral dissertation). Available from ProQuest Dissertations and Theses database. (UMI No. 3148025)

21. Bundy-Fazioli, K., Quijano, M.L., \& Bubar, R. (2013). Graduate Students' Perceptions of Professional Power in Social Work Practice. Journal of Social Work Education, 49(1), 108121. https://doi.org/10.1080/10437797.2013.755092

22. Cellich, C., \& Jain, S. (2012). Practical Solutions to Global Business Negotiations. New York : Business Expert Press.

23. Jonsson,Ch. (1990). Communication in International Bargaining. London : Pinter Publishers.

24. Kariaka, I. (2017). Value-semantic orientations as a factor of students-psychologists' behavior forming. Nauka $i$ osvita - Science and Education, 11, 146-150. https://doi.org/10.24195/2414-4665-2017-11-19

25. Koval, G., Sanzharovets, V., \& Shatylo, Yu. (2020). Social Works in Certain Areas of Donetsk and Lugansk Regions. Atlantis Press. Advances in Economics, Business and Management Research, 129, 361-369. https://doi.org/10.2991/aebmr.k.200318.045

26. McGuire, R. (2004). Negotiation: An important life skill. The Pharmaceutical Journal (PJ), 273, 23-25. Retrieved from https://www.pharmaceutical-journal.com/careers-andjobs/careers-and-jobs/career-feature/negotiation-an-important-life-skill/10997072.article

27. Pitcher, D. (2008). Social work and power [Review of the book Social work and power, by R. Smith]. British Journal of Social Work, 38, 1660-1662. 
https://doi.org/10.1093/bjsw/bcn158

28. Sharma, S., Bottom, W.P., \& Elfenbein, H.A. (2013). On the role of personality, cognitive ability, and emotional intelligence in predicting negotiation outcomes. Organizational Psychology Review, 3(4), 293-336. https://doi.org/10.1177/2041386613505857

29. Stein, J.G. (1988). International Negatiation: A Multidisciplinary Perspective. Negotiation Journal, 4, 221-231. https://doi.org/10.1111/j.1571-9979.1988.tb00467.x

30. Thomson, L. (1990). Negotiation behavior and outcomes: Empirical evidence and theoretical issues. Psychological Bulletin, 108(3), 515-532.

https://doi.org/10.1037/0033-2909.108.3.515

\title{
PSYCHOLOGICAL FEATURES OF THE DEVELOPMENT OF COMMUNICATIVE NEGOTIATION SKILLS IN FUTURE SOCIAL WORKERS Valentyna Sanzharovets \\ PhD in Philosophy, Associate Professor of the Department of Social Technologies
} National Aviation University

1, Lubomir Husar Avenu, Kyiv, Ukraine, 03058

valyasan@ukr.net, http://orcid.org/0000-0002-5213-9093

\author{
Juliia Shatylo \\ PhD in Psychology, Associate Professor of the Department of Social Technologies \\ National Aviation University \\ 1, Lubomir Husar Avenu, Kyiv, Ukraine, 03058 \\ yuliyashatylo89@gmail.com, http://orcid.org/0000-0002-5021-2787
}

\begin{abstract}
The article is devoted to the analysis of features of effective professional communication of the future specialist of the social sphere. Qualification of future social workers presupposes the formation of many competencies that a graduate of the Faculty of Linguistics and Social Communications must possess in order to be competitive in the labor market. Such competencies include: the ability of a consultant, consultant and expert, the ability to negotiate on various issues of clients of social work, social assistance, advocacy of the child. Competitiveness in the labor market also largely depends on the ability of the specialist to adapt to often changing conditions. The success of negotiations depends on the effectiveness of communicative behavior of the future social worker. Ability to conduct quality business communication in various (including problematic) situations of professional interaction, the ability to negotiate at various levels with representatives of governmental and non-governmental organizations, professionally persuade clients, interlocutors, establish emotional contact, listen carefully are necessary components of social services. However, the insufficient level of development of future social workers' communication skills, which are an important element in the system of their communicative competence, leads to an increase in the duration of adaptation of the future specialist in the professional environment and reduce the success of his work. As a result of the study, many subjects found a fairly high rate of aggression as the dominant strategy of psychological protection; tendency to predominant use of peace as a strategy of psychological protection, which, although positive strategies, but their use in some situations of professional activity may indicate a lack of ability of future social workers to defend their position, their excessive flexibility in communicating with clients. A large number of subjects with a low level of communicative control have been identified, which obviously reduces the effectiveness of their professional communication due to excessive straightforwardness and obsession.

Keywords: communicative negotiation skills, professional-communicative competence, specialists in the social sphere, psychological characteristics, information-communicative component, expressive-perceptual component, interpersonal component.
\end{abstract}

Подано 21.04.2020

Рекомендовано до друку 29.04.2020 